https://helda.helsinki.fi

\title{
Histamine receptors
}

\section{Haas, Helmut L.}

2016-07

Haas, H L \& Panula , P 2016 , ' Histamine receptors ', Neuropharmacology , vol. 106 , pp.

1-2 . https://doi.org/10.1016/j.neuropharm.2016.04.007

http://hdl.handle.net/10138/224101

https://doi.org/10.1016/j.neuropharm.2016.04.007

publishedVersion

Downloaded from Helda, University of Helsinki institutional repository.

This is an electronic reprint of the original article.

This reprint may differ from the original in pagination and typographic detail.

Please cite the original version. 
Editorial

\section{Histamine receptors}

Histamine and its receptors in the nervous system received recognition late in comparison to the other aminergic transmitters, after the detection of histaminergic neurons in the posterior hypothalamus (Panula et al., 1984; Watanabe et al., 1984). Four G-protein coupled receptors have been identified in vertebrates (Panula et al., 2015), at least 3 of which fulfill important functions in the brain. $\mathrm{H}_{1}$ Rs mediate mostly neuronal excitation and are blocked by the classical antihistamines causing sedation, $\mathrm{H}_{2} \mathrm{R}$ activation also excites certain neurons, $\mathrm{H}_{2} \mathrm{R}$-antagonists revolutionized stomach ulcer treatment and $\mathrm{H}_{3} \mathrm{Rs}$ are inhibitory autoreceptors and heteroreceptors with complex pre- and postsynaptic functions. For the most recently described $\mathrm{H}_{4} \mathrm{R}$ mediation of neural actions are so far uncertain. In this issue a number of specific functions in the nervous system are reviewed or presented by authors using different approaches and methods from molecules to mind, from synapse to behavior. Whereas the cloning of the $\mathrm{H}_{3} \mathrm{R}$ (Lovenberg et al., 1999) transformed the drug development for this target, the $\mathrm{H}_{1} \mathrm{R}$ and $\mathrm{H}_{2} \mathrm{R}$ are still being investigated as important postsynaptic histamine receptors in the brain. For example, the metabolic side effects of antipsychotics are largely due to $\mathrm{H}_{1} \mathrm{R}$ antagonism in the hypothalamus. In this issue Provensi et al. 2016 review feeding disorders and therapeutic opportunities to prevent obesity and metabolic syndrome. Tabarean (2016) treats the role of histamine receptors in the hypothalamic energy homeostasis. Parmentier et al. (2016) demonstrate the prominent role of the $\mathrm{H}_{1} \mathrm{R}$ in cortical activation. J-C Schwartz (2016) who made major discoveries in the field since almost half a century, detected the $\mathrm{H}_{3} \mathrm{R}$ and, together with J-M Lecomte developed the first $\mathrm{H}_{3} \mathrm{R}$ antagonist/inverse agonist drug that just entered the market (Wakix).

There is evidence from clinical studies that $\mathrm{H}_{2} \mathrm{R}$ antagonists may be useful in schizophrenia, but no new brain-penetrating drugs have been developed. The potential of $\mathrm{H}_{3} \mathrm{R}$ antagonists in brain disorders is still evident, although their capacity to improve cognition has not been shown in clinical studies. They are being used to treat sleep/wakefulness disorders. Animal studies from several laboratories have shown that $\mathrm{H}_{3} \mathrm{R}$ antagonists inhibit alcohol drinking, alcohol-induced place preference and cue-induced reinstatement of alcohol seeking. However, clinical studies have not been carried out. Several histamine $\mathrm{H}_{3} \mathrm{R}$ antagonists have been developed over the last decade but only one has been filed so far (Dauvilliers et al., 2013). Hudkins et al. (2016) and Sadek et al. (2016) describe the production, development and testing of new $\mathrm{H}_{3} \mathrm{R}$ antagonists. Furthermore Sadek and Stark (2016) compare the affinity, selectivity and efficacy of typical ligands for all histamine receptors.

Bolam and Ellender (2016) review the complex mechanisms by which histamine regulates striatal functions through $\mathrm{H}_{1} \mathrm{R}, \mathrm{H}_{2} \mathrm{R}$ and $\mathrm{H}_{3} \mathrm{R}$. Keeping in mind that many other parts of the motor system, including the thalamus and cortex, also are regulated by histamine, the complexity of this system is evident. Histamine interacts with many other neurotransmitter systems. An important finding was that lack of histamine synthesis due to a mutation in the synthesizing enzyme histidine decarboxylase is associated with Gilles de la Tourette syndrome (Ercan-Sencicek et al., 2010). Subsequently, histaminergic regulation of the striatum has become an important field (Rapanelli and Pittenger, 2016). In the striatal areas, including the nucleus caudatus and accumbens, interactions with dopamine are particularly important (Aquino-Miranda et al., 2016). DeLuca et al. (2016) report a dopaminergic neuron group in the tuberomamillary nucleus and revisit the $\mathrm{H}_{3} \mathrm{R}$ autoreceptor function.

A role of the $\mathrm{H}_{4} \mathrm{R}$ in brain has not been conclusively shown: some studies have suggested the presence of this receptor in neurons, whereas others have not found evidence of neuronal expression. Some of the early experimental $\mathrm{H}_{3} \mathrm{R}$ drugs have later proven to be good ligands at $\mathrm{H}_{4} \mathrm{R}$ as well, which may complicate interpretation of pharmacological studies. There is evidence of $\mathrm{H}_{4} \mathrm{R}$ expression in non-neuronal cells in the brain. The importance of the tools used to assess the role of histamine receptors in the brain is emphasized in the review by Schneider et al. (2016). They conclude that there is no evidence so far for $\mathrm{H}_{4} \mathrm{R}$ expression and function in nervous tissue. Petri et al. (2016) investigated the presynaptic interaction of $\mathrm{H}_{3} \mathrm{R}$ and $\mathrm{H}_{4} \mathrm{R}$ on four peripheral tissues and one brain tissue model in vitro. Only $\mathrm{H}_{3} \mathrm{R}$ activation reduced the release of other transmitters, none of the synaptic sites displayed $\mathrm{H}_{4} \mathrm{R}$ mediated effects.

Zlomuzica et al. (2016) review the role of histamine and its receptors in cognition and possible prevention of cognitive decline in Alzheimer's dementia. Yeung et al. (2016) show ventral hippocampal infusions of histamine causing anxiolysis and an increase in theta activity, whereas the anxiolytic diazepam reduces theta. These results question the functional role of theta frequency depression in the hippocampus for anxiolysis. Nuutinen et al. (2016) report the effects of $\mathrm{H}_{3} \mathrm{R}$ antagonism on motivational aspects of alcohol reinforcement and suggest a therapeutic strategy to reduce craving and to prevent relapse.

The histaminergic system in brain is recognized now as a major player in the ascending activation of the forebrain, the hypothalamic homeostasis and the endocrine system (Haas et al., 2008) and histamine receptors are still actively explored on a wide range of therapeutic targets. This motivated us to assemble a number of reviews and research papers in this special issue. 


\section{References}

Aquino-Miranda, G., Escamilla-Sánchez, J., González-Pantoja, R., Bueno-Nava, A., Arias-Montaño, J.A., 2016. Histamine H3 receptor activation inhibits dopamine synthesis but not release or uptake in rat nucleus accumbens. Neuropharmacology 106, 91-101. http://dx.doi.org/10.1016/j.neuropharm.2015.07.006.

Bolam, J.P., Ellender, T.J., 2016. Histamine and the striatum. Neuropharmacology 106, 74-84. http://dx.doi.org/10.1016/j.neuropharm.2015.08.013.

De Luca, R., Suvorava, T., Yang, D., Baumgärtel, W., Kojda, G., Haas, H.L., Sergeeva, O.A., 2016. Identification of histaminergic neurons through histamine 3 receptor-mediated autoinhibition. Neuropharmacology 106, 102-115. http:// dx.doi.org/10.1016/j.neuropharm.2015.08.025.

Dauvilliers, Y., Bassetti, C., Lammers, G.J., Arnulf, I., Mayer, G., Rodenbeck, A., Lehert, P., Ding, C.L., Lecomte, J.M., Schwartz, J.C., HARMONY I study group, 2013. Pitolisant versus placebo or modafinil in patients with narcolepsy: a double-blind, randomised trial. Lancet Neurol. 12, 1068-1075.

Ercan-Sencicek, A.G., Stillman, A.A., Ghosh, A.K., Bilguvar, K., O'Roak, B.J., Mason, C.E., Abbott, T., Gupta, A. King, R.A., Pauls, D.L. Tischfield, J.A., Heiman, G.A., Singer, H.S., Gilbert, D.L., Hoekstra, P.J., Morgan, T.M., Loring, E., Yasuno, K., Fernandez, T., Sanders, S., Louvi, A., Cho, J.H., Mane, S., Colangelo, C.M., Biederer, T., Lifton, R.P., Gunel, M., State, M.W., 2010. L-histidine decarboxylase and Tourette's syndrome. N. Engl. J. Med. 362, 1901-1908.

Haas, H.L., Sergeeva, O.A., Selbach, O., 2008. Histamine in the nervous system. Physiol. Rev. 88, 1183-1242.

Hudkins, R.L., Gruner, J.A., Raddatz, R., Mathiasen, J.R., Aimone, L.D., Marino, M.J. Bacon, E.R., Williams, M., Ator, M.A., 2016. 3-(1'-Cyclobutylspiro [4H-1, 3-benzodioxine-2, 4'-piperidine]-6-yl)-5, 5-dimethyl-1, 4-dihydropyridazin-6-one (CEP32215), a new wake-promoting histamine $\mathrm{H} 3$ antagonist/inverse agonist. Neuropharmacology 106, 37-45. http://dx.doi.org/10.1016/j.neuropharm.2015.09.025.

Lovenberg, T.W., Roland, B.L., Wilson, S.J., Jiang, X., Pyati, J., Huvar, A., Jackson, M.R., Erlander, M.G., 1999. Cloning and functional expression of the human histamine H3 receptor. Mol. Pharmacol. 55, 1101-1107.

Nuutinen, S., Mäki, T., Rozov, S., Bäckström, P., Hyytiä, P., Piepponen, P., Panula, P., 2016. Histamine H3 receptor antagonist decreases cue-induced alcohol reinstatement in mice. Neuropharmacology 106, 156-163.

Panula, P., Chazot, P.L., Cowart, M., Gutzmer, R., Leurs, R., Liu, W.L., Stark, H. Thurmond, R.L., Haas, H.L., 2015. International union of basic and clinical pharmacology. XCVIII. Histamine receptors. Pharmacol. Rev. 67, 601-655.

Panula, P., Yang, H.Y., Costa, E., 1984. Histamine-containing neurons in the rat hypothalamus. Proc. Natl. Acad. Sci. U. S. A. 8, 2572-2576.

Parmentier, R., Zhao, Y., Perier, M., Akaoka, H., Lintunen, M., Hou, Y., Panula, P., Watanabe, T., Franco, P., Lin, J.S., 2016. Role of histamine H1-receptor on behavioral states and wake maintenance during deficiency of a brain activating system: a study using a knockout mouse model. Neuropharmacology 106, 20-34. http://dx.doi.org/10.1016/j.neuropharm.2015.12.014.

Petri, D., Schlicker, E., 2016. A search for presynaptic inhibitory histamine receptors in guinea-pig tissues: Further $\mathrm{H} 3$ receptors but no evidence for H4 receptors. Neuropharmacology 106,129-134. http://dx.doi.org/10.1016/j.neuropharm.2015.06.020.

Provensi, G., Blandina, P., Passani, M.B., 2016. The histaminergic system as a target for the prevention of obesity and metabolic syndrome. Neuropharmacology
106, 3-12. http://dx.doi.org/10.1016/j.neuropharm.2015.07.002.

Rapanelli, M. Pittenger, C., 2016. Histamine and histamine receptors in Tourette syndrome and other neuropsychiatric conditions. Neuropharmacology 106 85-90. http://dx.doi.org/10.1016/j.neuropharm.2015.08.019.

Watanabe, T., Taguchi, Y., Shiosaka, S., Tanaka, J., Kubota, H., Terano, Y., Tohyama, M. Wada, H., 1984. Distribution of the histaminergic neuron system in the central nervous system of rats; a fluorescent immunohistochemical analysis with histidine decarboxylase as a marker. Brain Res. 295, 13-25.

Tabarean, I.V., 2016. Histamine receptor signaling in energy homeostasis. Neuropharmacology 106, 13-19. http://dx.doi.org/10.1016/j.neuropharm.2015.04.011.

Schwartz, J.C., Lecomte, J.M., 2016. Clinical trials with H3-receptor inverse agonists: What they tell us about the role of histamine in the human brain. Neuropharmacology 106, 35-36. http://dx.doi.org/10.1016/j.neuropharm.2016.04.006.

Sadek, B., Saad, A., Subramanian, D., Shafiullah, M., Łażewska, D. Kieć-Kononowiczc, K., 2016. Anticonvulsant and procognitive properties of the non-imidazole histamine $\mathrm{H} 3$ receptor antagonist DL77 in male adult rats. Neuropharmacology 106, 46-55. http://dx.doi.org/10.1016/j.neuropharm.2015.10.023.

Sadek, B., Stark, H., 2016. Cherry-picked ligands at histamine receptor subtypes. Neuropharmacology 106, 56-73. http://dx.doi.org/10.1016/j.neuropharm.2015.11.005.

Schneider, E.H., Seifert, R., 2016. The histamine H 4-receptor and the central and peripheral nervous system: a critical analysis of the literature. Neuropharmacology 106, 116-128. http://dx.doi.org/10.1016/j.neuropharm.2015.05.004.

Yeung, M., Treit, D., Dickson, C.T., 2016. Ventral hippocampal histamine increases the frequency of evoked theta rhythm but produces anxiolytic-like effects in the elevated plus maze. Neuropharmacology 106, 146-155. http://dx.doi.org 10.1016/j.neuropharm.2015.09.024.

Zlomuzica, A., Dere, D., Binder, S., Silva, M.A.D.S., Huston, J.P., Dere, E., 2016. Neuronal histamine and cognitive symptoms in Alzheimer's disease. Neuropharmacology 106, 135-145. http://dx.doi.org/10.1016/j.neuropharm.2015.05.007.

Helmut L. Haas*

Institut für Neurophysiologie, Heinrich-Heine-Universität, 40204

Düsseldorf, Germany

Pertti Panula**

Department of Anatomy and Neuroscience Centre, University of Helsinki, Haartmaninkatu 8, 00290 Helsinki, Finland

* Corresponding author.

${ }^{* *}$ Corresponding author.

E-mail address: haas@uni-duesseldorf.de (H.L. Haas). E-mail address: pertti.panula@helsinki.fi (P. Panula).

Available online 14 April 2016 